\title{
The red clover (Trifolium pratense) isoflavone biochanin A inhibits aromatase activity and expression
}

\author{
Yun Wang ${ }^{1}$, Wai Man Gho', Franky L. Chan ${ }^{2}$, Shiuan Chen $^{3}$ and Lai K. Leung ${ }^{1,4 *}$ \\ ${ }^{1}$ Department of Biochemistry, The Chinese University of Hong Kong, Shatin NT, Hong Kong \\ ${ }^{2}$ Department of Anatomy, The Chinese University of Hong Kong, Shatin NT, Hong Kong \\ ${ }^{3}$ Division of Immunology, Beckman Research Institute of the City of Hope, Duarte, CA 91010, USA \\ ${ }^{4}$ Food and Nutritional Sciences Programme, The Chinese University of Hong Kong, Shatin NT, Hong Kong \\ (Received 8 February 2007 - Revised 22 June 2007 - Accepted 25 June 2007)
}

Biochanin A is an isoflavone isolated from red clover (Trifolium pratense), and is a commercially available nutraceutical for women suffering from postmenopausal symptoms. Isoflavones resemble the structure of oestrogen, and display agonistic and antagonistic interactions with the oestrogen receptor. Overexposure of oestrogen is a major contributing factor in the development of breast cancer, and cytochrome P450 (CYP) 19 enzyme, or aromatase, catalyses the reaction converting androgen to oestrogen. In the present study the effect of biochanin A on the gene regulation and enzyme activity of aromatase was investigated. By assaying MCF-7 cells stably transfected with CYP19, biochanin A inhibited aromatase activity and hampered cell growth attributing to the enzyme activity. In addition, $25 \mu \mathrm{M}$-biochanin A significantly reduced CYP19 mRNA abundance in the oestrogen receptor-negative breast cancer cells SK-BR-3. The transcriptional control of the CYP19 gene is exon-specific, and promoter regions I.3 and II have been shown to be responsible for CYP19 expression in SK-BR-3 cells. Luciferase reporter gene assays also revealed that biochanin A could repress the transcriptional control dictated by the promoter regulation. Interestingly, genistein did not inhibit aromatase but it might down regulate promoter I.3 and II transactivation. Since genistein is a major metabolite of biochanin A, it might contribute to biochanin A's suppressive effect on CYP19 expression. The present study illustrated that biochanin A inhibited CYP19 activity and gene expression.

Biochanin A: Aromatase: Breast cancer cells

Epidemiological studies have shown that the use of exogenous oestrogen ${ }^{1,2}$ or an augmented endogenous oestrogen concentration $^{3,4}$ is associated with increased breast cancer risk. In both cell and animal models a causal relationship between oestrogen exposure and breast cancer has also been established ${ }^{5}$.

The cancer-inducing mechanisms of oestrogen in the breast can be multifaceted, and may participate in either the initiation or promotion stage. Oestrogen can be metabolised into various catechol oestrogens, and oestrogen-2-hydroxylase and oestrogen-4-hydroxylase are cytochrome P450 (CYP) enzymes that hydroxylate oestrogen at the $\mathrm{C}-2$ and $\mathrm{C}-4$ positions, respectively $^{6}$. These hydroxylated metabolites can further be converted into quinone and semiquinone structures, which have been shown to be carcinogenic in animal models ${ }^{7,8}$. In addition, free radicals generated by some of these metabolites may cause oxidative DNA damage ${ }^{9}$. These genotoxic effects of oestrogen have been demonstrated in MCF-7 cells ${ }^{10}$ and rat mammary tissues ${ }^{11}$.

The notion that oestrogen promotes breast cancer is reinforced in a transgenic mouse model that develops spontaneous mammary tumours. Treatment with oestrogen accelerates the development of neoplastic lesions and carcinomas in these mice ${ }^{12}$. Oestrogen-induced cell proliferation has been a major focus in breast cancer research. The pertained mechanisms lie in the regulation of cell-cycle ${ }^{13,14}$ Bcl-2 family protein expression ${ }^{15}$, and the interaction with plasma membrane receptors ${ }^{16}$.

Oestrogen is synthesised from cholesterol in several steps, and CYP19 (aromatase) catalyses the final rate-limiting reaction. Aromatase is encoded by a single-copy gene ${ }^{17,18}$. The promoter utilisation for $C Y P 19$ regulation varies in different tissues, which provides the basis for tissue-specific expression $^{19}$. Polymorphisms in the CYP19 gene have been associated with breast cancer risk ${ }^{20}$. Many aromatase inhibitors have recently been developed, and some of them are promising agents for breast cancer prevention and therapy ${ }^{21}$.

Some flavones have been documented to be aromatase inhibitors. The $\mathrm{A}$ and $\mathrm{C}$ rings of flavones may compete with the $\mathrm{C}$ and $\mathrm{D}$ rings of the androgen structure for binding to the active site 22 . Isoflavones are another class of flavonoids whose chemical structures highly resemble that of flavones. Nevertheless, biochanin A is the only aromatase-inhibitory isoflavone with reported $50 \%$ inhibitory concentration $\left(\mathrm{IC}_{50}\right)$

Abbreviations: CYP, cytochrome P450; $\mathrm{IC}_{50}, 50 \%$ inhibitory concentration.

* Corresponding author: Dr Lai K. Leung, fax +852 26037732, email laikleung@cuhk.edu.hk 
values varying from about $10 \mu \mathrm{M}$ to $113 \mu \mathrm{M}^{22-25}$. We would like to examine and clarify the CYP19 inhibitory potential of the isoflavone and its effect on mRNA expression specifically driven by promoters I.3 and II in the present study. Since promoters I. 3 and II are typically employed in breast cancerous tissues ${ }^{26}$, suppression on these promoters would halt oestrogen supply for their growth and development.

\section{Materials and methods}

\section{Chemicals}

Biochanin A was obtained from Sigma Chemicals (St Louis, MO, USA). All chemicals, if not stated, were purchased from Sigma Chemicals.

\section{Cell culture}

The breast cancer cell line SK-BR-3 was a generous gift from Dr Richard K. W. Choy (Obstetrics and Gynaecology Department, the Chinese University of Hong Kong, Kowloon, Hong Kong) and MCF-7 cells were obtained from the American Tissue Culture Collection (Rockville, MD, USA). MCF-7 cells stably transfected with human CYP19 (MCF-7aro) were prepared as previously described ${ }^{27}$.

The stably transfected MCF-7 cells were maintained in Eagle's minimum essential medium (Invitrogen, Grand Island, NY, USA) supplemented with $10 \%$ fetal bovine serum (Invitrogen Life Technology, Rockville, MD, USA) and the selective antibiotic G418 $(500 \mu \mathrm{g} / \mathrm{ml}$; USB, Cleveland, OH, USA). SK-BR-3 cells were cultured in McCoy's 5A medium (Sigma Chemicals) with $10 \%$ fetal bovine serum. Cells were incubated at $37^{\circ} \mathrm{C}$ and $5 \%$ carbon dioxide, and were routinely sub-cultured when reaching $80 \%$ of confluency. Biochanin A was administered in the solvent vehicle dimethyl sulfoxide, and the concentration was limited to $0.1 \%$ $(\mathrm{v} / \mathrm{v})$. Cells were seeded uniformly at a density of $5 \times 10^{2}$ cells $/ \mathrm{mm}^{2}$ in all experiments.

\section{'In-cell' aromatase assays}

The assays were performed as previously described ${ }^{28}$. In brief, MCF-7aro cells were seeded and allowed $1 \mathrm{~d}$ for attachment. Assays were started by replacing the culture medium with serum-free medium containing $\left[1 \beta-{ }^{3} \mathrm{H}\right]$ androstenedione and biochanin $\mathrm{A}$. The final concentration of androstenedione was controlled at $25 \mathrm{nM}$, and the reaction was incubated at $37^{\circ} \mathrm{C}$ for $1 \mathrm{~h}$. A sample of the medium was then mixed with an equal volume of chloroform, followed by a $10000 \mathrm{~g}$ centrifugation at $4^{\circ} \mathrm{C}$ for $10 \mathrm{~min}$. The aqueous phase was removed into a new tube containing $500 \mu \mathrm{l}$ of $5 \%$ activated charcoal suspension. After $30 \mathrm{~min}$ incubation, a sample of the supernatant fraction was taken out for scintillation counting. The protein content of the cells, on the other hand, was determined by using a BCA kit (Sigma Chemicals) after dissolving the cells in $0 \cdot 5 \mathrm{M}-\mathrm{NaOH}$.

A similar protocol was applied to assays performed on SK-BR-3 cells, except that the assays were designed to determine the level of expression as described previously ${ }^{29}$.
In brief, the cells were seeded in twelve-well plates at a density of $2 \times 10^{5}$ per well. Biochanin A was administered in the cell cultures and incubated for $24 \mathrm{~h}$ before adding the substrate $\left[1 \beta-{ }^{3} \mathrm{H}(\mathrm{N})\right]$ androst-4-ene-3, 17-dione. The reaction was further incubated at $37^{\circ} \mathrm{C}$ for $3 \mathrm{~h}$ before the assay was performed.

For the enzyme inhibition assays performed on recombinant protein, 2 pmol Supersomes ${ }^{\circledR}$ was incubated with biochanin A and the substrate-containing assay buffer $\left(25 \mathrm{nM}-\left[1 \beta-{ }^{3} \mathrm{H}(\mathrm{N})\right]\right.$ androst-4-ene-3, 17-dione, $3.3 \mathrm{~mm}-\mathrm{MgCl}_{2}, 100 \mathrm{mM}-\mathrm{KH}_{2} \mathrm{PO}_{4}$ $(\mathrm{pH} 7 \cdot 4)$ ). The reaction was initiated by the addition of $1.3 \mathrm{~mm}-\mathrm{NADPH}$ and incubated at $37^{\circ} \mathrm{C}$ for $15 \mathrm{~min}$.

\section{Quantitative real-time polymerase chain reaction assay}

In order to quantify the suppression of mRNA abundance, a cell line with reasonable amount of aromatase expression had to be used. Because aromatase mRNA was barely detectable in wild-type MCF-7 cells, we employed an aromatase-expressing cell line (SK-BR-3) for this assay. The real-time quantitative PCR was carried out as previously described by our laboratory ${ }^{29}$. In brief, CYP19 and $\beta$-actin cDNA fragments were amplified and cloned into pGEMT-Easy vector (Promega Corp., Madison, WI, USA) as templates for quantifying the absolute amount of mRNA expression. Plasmids containing the respective amplicon - pGEMT-CYP19 and pGEMT- $\beta$-actin - were sequenced and stored at $-20^{\circ} \mathrm{C}$ until use. SK-BR-3 cells were cultured and treated as described earlier. After $24 \mathrm{~h}$ of treatment, total RNA was extracted from the cells using TRIzol reagent (Invitrogen, Carlsbad, CA, USA). The concentration and purity of the isolated RNA were determined by the absorbance reading observed at 260 and $280 \mathrm{~nm}$. Total RNA $(3 \mu \mathrm{g})$, oligo-dT, and M-MLV Reverse Transcriptase (USB Corporation, Cleveland, OH, USA) were used for first strand synthesis. Target fragments were quantified by real-time PCR and an Opticon ${ }^{\mathrm{TM}} 2$ system (MJ Research, Waltham, MA, USA). CYP19 copy number was determined by absolute quantification. A standard curve was constructed by 10 -fold serial dilutions from 10 to $10^{7}$ copies amplified from pGEMT-CYP19 or pGEMT- $\beta$-actin. Sample copy number was read from the standard curve. A SYBR green PCR Master Mix Reagent kit was obtained from Applied Biosystems and PCR reactions were set up as described in the manual. A typical reaction contained $200 \mathrm{nmol} / \mathrm{l}$ of forward and reverse primer, $2 \mu \mathrm{l} \mathrm{cDNA}$ and the final reaction volume was $20 \mu \mathrm{l}$. The reaction was initiated by preheating at $50^{\circ} \mathrm{C}$ for $2 \mathrm{~min}$, followed by $95^{\circ} \mathrm{C}$ for $10 \mathrm{~min}$. Subsequently, forty-five amplification cycles were then carried out with $15 \mathrm{~s}$ denaturation at $95^{\circ} \mathrm{C}$ and $1 \mathrm{~min}$ annealing and extension at $58^{\circ} \mathrm{C}$. Copies of $\beta$-actin RNA were also determined and used for normalisation. The forward and reverse primers designed for CYP19 were $5^{\prime}$-ATC TCT GGA GAG GAA ACA CTC ATTA $-3^{\prime}$ and $5^{\prime}-\mathrm{CTG}$ ACA GAG CTT TCA TAA AGA AGGG-3'; the forward and reverse primers for $\beta$-actin were $5^{\prime}-\mathrm{CAC}$ CAA CTG GGA CGA CAT-3' and $5^{\prime}-$ AGG CGT ACA GGG ATA GCA-3'. Dissociation curve and gel image analysis did not review non-specific amplifications generated from these primers. 


\section{Measurement of cell viability}

Cell number was assessed by 3-(4, 5-dimethylthiazol-2-yl)-2, 5-diphenyl tetra-zolium bromide (MTT) staining as described by Mosmann $^{30}$. Briefly, MCF-7aro cells were seeded in ninety-six-well plates and maintained in Eagle's minimal essential medium supplemented with $10 \%$ charcoal dextrantreated serum (Hyclone, Logan, UT, USA). The cells were allowed $24 \mathrm{~h}$ for attachment and they were treated with testosterone and/or biochanin A for $48 \mathrm{~h}$. At the end of the treatment, $50 \mu \mathrm{l}$ of MTT $(1 \mathrm{mg} / \mathrm{ml})$ was added to the cells and incubated at $37^{\circ} \mathrm{C}$ for $4 \mathrm{~h}$. Cell viability was assessed with respect to the absorbance at $544 \mathrm{~nm}$.

\section{Luciferase gene reporter assay}

Construction of CYP19 promoter-driven reporter plasmid. A human CYP19 gene fragment $(-446 /+118)$ upstream to exon II was amplified from genomic DNA isolated from SK-BR-3 cells. The promoters I. 3 and II $^{26}$ have been reported to be associated with $C Y P 19$ expression in breast cancer cells. Primers were designed with the incorporation of KpnII and XhoI restriction sites. The amplified products were then digested and subcloned into a firefly luciferase reporter vector pGL3 basic (Promega Corp.), and the sequences were verified.

Dual luciferase assays. SK-BR-3 cells were plated in twenty-four-well dishes. After $24 \mathrm{~h}$, the cells were transiently transfected with $0.25 \mu \mathrm{g}$ of the CYP19 reporter plasmid and $2.0 \mathrm{ng}$ of renilla luciferase control vector pRL (Promega Corp.) in LipofectAmine reagent (Invitrogen Life Technologies). After $1 \mathrm{~d}$, the medium was removed and the cells were treated with biochanin A for $24 \mathrm{~h}$. The cells were lysed and the activities of the luciferases were determined using the Dual-Luciferase Assay Kit (Promega Corp.). The luciferase bioluminescence was quantified by using a FLUOstar Galaxy plate reader (BMG Labtechnologies GmBH, Offenburg, Germany). The transactivation activities of the CYP19 promoter represented by firefly luciferase light units were then normalised with that of renilla luciferase.

\section{Western analysis}

Cells were washed once by PBS ( $\mathrm{pH} 7.4)$ and harvested into a $1.5 \mathrm{ml}$ microtube with $0.5 \mathrm{ml}$ lysis buffer (PBS, $1 \% \mathrm{NP} 40$, $0.5 \%$ sodium deoxycholate, $0.1 \%$ SDS). The lysis buffer contained protease inhibitors (phenylmethylsulfonyl fluoride $(40 \mathrm{mg} / \mathrm{l})$, aprotinin $(0.5 \mathrm{mg} / \mathrm{l})$, leupeptin $(0.5 \mathrm{mg} / \mathrm{l}), 1.1 \mathrm{~mm}-$ EDTA and pepstatin $(0.7 \mathrm{mg} / \mathrm{l}))$. The harvested cells were then lysed with a cell disruptor (Branson Ultrasonics Corp., Danbury, CT, USA) on ice for $30 \mathrm{~s}$. The protein concentration of cell lysate was determined by the Dc protein assay (BioRad, Richmond, CA, USA). Lysate protein $(50 \mu \mathrm{g})$ was separated on $10 \%$ SDS-PAGE and transferred onto an Immobilon PVDF membrane (Millipore, Bedford, MA, USA). AntiCYP19 (ABcam plc, Cambridge, UK), anti-actin primary (Sigma Chemicals) and secondary antibodies conjugated with horseradish peroxidase (Santa Cruz Biotechnology, Inc., Santa Cruz, CA, USA) were used for protein detection. An ECL Detection Kit (Amersham, Arlington Heights, IL, USA) provided the chemiluminescence substrate for horseradish peroxidase, and the targeted protein was visualised by autoradiography.

\section{Statistical methods}

A Prism ${ }^{\circledR} 3.0$ (GraphPad Software, Inc., CA, USA) software package was utilised for statistical analysis. The results were analysed by one-way ANOVA followed by Bonferroni's multiple comparison test if significant differences $(P<0.05)$ were observed. The $t$ test was employed for comparison of the means between biochanin A-treated and control cultures. Another software package, SigmaPlot (SPSS Inc., Chicago, IL, USA), was used for graphing the Lineweaver-Burk plots.

\section{Results}

\section{Biochanin A inhibited aromatase enzymic activity}

Enzyme inhibition assay performed on MCF-7aro cells and recombinant protein. A previous study ${ }^{31}$ has shown that MCF-7aro cells can be used for enzyme inhibition analysis. Biochanin A displayed an inhibitory effect with an $\mathrm{IC}_{50}$ value of about $8 \mu \mathrm{M}$ in the MCF-7aro cells (Fig. 1 (A)). No significant drop in activity was observed in other isoflavones. The enzyme inhibition was further confirmed in the recombinant enzyme system (human CYP19 Supersomes ${ }^{\circledR}$; BD Gentest, Woburn, MA, USA) and the $\mathrm{IC}_{50}$ value was determined to be $12.5 \mu \mathrm{M}$ (Fig. 1 (B)).

Enzyme kinetic assay. Five concentrations, i.e. 0, 6·25, $12.5,25$ and $50 \mu \mathrm{M}$-biochanin $\mathrm{A}$, were selected for kinetic analysis. A Lineweaver-Burk plot showed that biochanin A had a mixed type of inhibition on CYP19 with a $K_{\mathrm{i}}$ value of $10.8 \mu \mathrm{M}$ in MCF-7aro cells (Fig. 2).

Specific inhibition on testosterone-induced proliferation in MCF-7aro cells. Biochanin A was able to reduce the testosterone-induced proliferation of MCF-7aro cells through the inhibition of aromatase (Fig. 3). The administration of $10 \mathrm{~nm}$-testosterone increased the cell number by $67 \%$ as shown at $0 \mu \mathrm{M}$-biochanin A. At $12.5 \mu \mathrm{M}$, biochanin A could significantly $(P<0.05)$ reduce the cell proliferation. At $25 \mu \mathrm{M}$, biochanin A brought down the testosterone-induced cell growth to a level comparable with their testosterone-less counterparts.

\section{Biochanin A suppressed CYP19 promoter I.3 and II-driven transactivation}

Effect of biochanin A on promoter I.3 and II activity of CYP19 in SK-BR-3 and MCF-7 cells. As the enzyme activity of CYP19 was reduced by biochanin A, we subsequently determined the transcriptional activity driven by promoter regions I.3 and II. We employed the breast cancer cell line SK-BR3, which had been demonstrated using promoters I.3 and II for CYP19 regulation ${ }^{26}$, for the assessment of promoter activity. At $50 \mu \mathrm{M}$, biochanin A was able to repress the promoter activity (Fig. 4 (A)) $(P<0 \cdot 05)$. Similar suppression was observed in MCF-7 cells (Fig. 4 (B)), and the down regulation on CYP19 transactivity appeared to be universal for breast cells.

Biochanin A reduced aromatase $m R N A$ and protein expression in SK-BR-3 cells. Quantitative RT-PCR indicated 

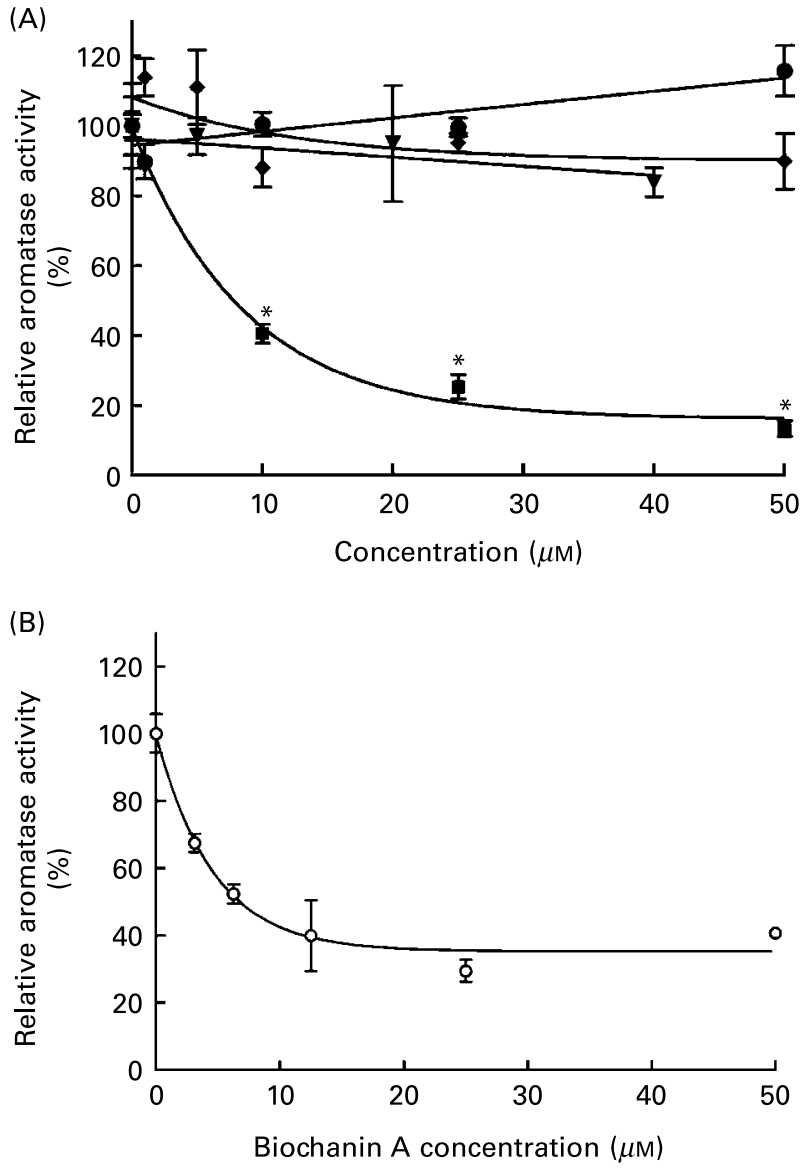

Fig. 1. Inhibitory effect of isoflavones (equol $(\mathbf{\nabla})$, genistein $(\bullet)$, daidzein $(\bullet)$ and biochanin A (ם)) on cytochrome P450 (CYP) 19 enzyme activity. MCF7aro cells were maintained in Eagle's minimum essential medium and switched to a serum-free medium upon assay. $\left[1 \beta^{3} \mathrm{H}\right]$ androstenedione and isoflavone were administered and incubated for $1 \mathrm{~h}$. Biochanin A was able to inhibit the enzyme at the range of concentrations tested, and the $50 \%$ inhibitory concentration $\left(\mathrm{IC}_{50}\right)$ value was $8 \mu \mathrm{M}$ (Fig. $1(\mathrm{~A})$ ). Assays performed in CYP19 recombinant protein also displayed similar inhibition with an $\mathrm{IC}_{50}$ value of $12.5 \mu \mathrm{M}$ (Fig. $1(\mathrm{~B})$ ). Values are means $(n 3)$, with their standard errors represeneted by vertical bars.

that the mRNA abundance of aromatase was reduced by biochanin A. Cultures treated with 12.5, 25 and $100 \mu \mathrm{M}$-biochanin A revealed significant drops in aromatase expression, and $100 \mu \mathrm{M}$ of the isoflavone could decrease the expression by more than $80 \%$ (Fig. 5 (A)). Western analysis also revealed a similar pattern (Fig. 5 (B)).

Aromatase activity in $S K-B R-3$ cells treated with biochanin $A$. Since the mRNA abundance could be suppressed by biochanin A, we measured the aromatase activity as an indicator for reduced expression. After $24 \mathrm{~h}$ of treatment the aromatase activity was found to be significantly reduced by $25 \mu \mathrm{M}$-biochanin A (Fig. 6).

A major metabolite of biochanin A - genistein - suppressed CYP19 promoter I.3 and II-driven transactivation

Effect of genistein on promoter I.3 and II activity of CYP19 in $S K-B R-3$ cells. Genistein is a major metabolite of biochanin A. Since biochanin A was shown to be active in suppressing CYP19 expression over a period of time, genistein might

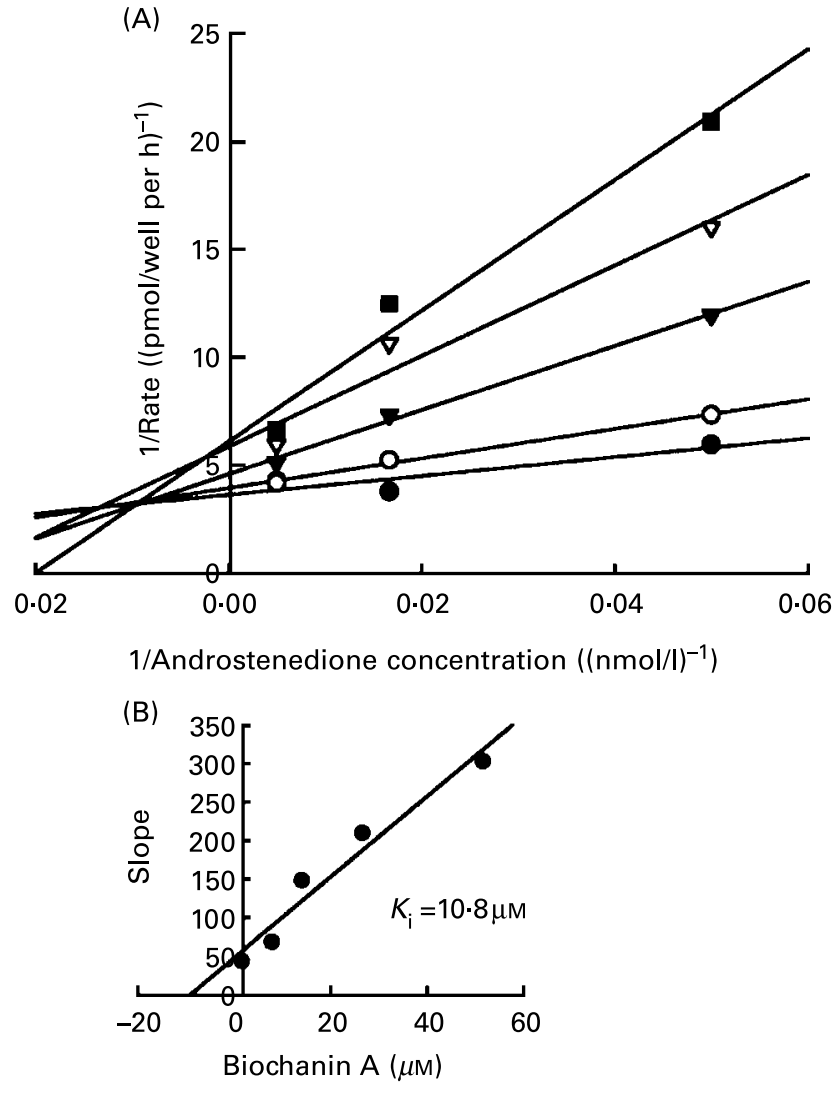

Fig. 2. Kinetic analysis of biochanin A inhibition on cytochrome P450 (CYP) 19. MCF-7aro cells were cultured and assayed for aromatase activity. Five concentrations of biochanin A $(0(\bullet), 6.25(\bigcirc), 12.5(\nabla), 25(\diamond)$ and $50(\boldsymbol{\nabla})$ $\mu \mathrm{M})$ were co-administered to the cells for the enzyme kinetic assay (A). The Lineweaver-Burk plot $(B)$ showed that biochanin A had a mixed type of inhibition on CYP19 with a $K_{\mathrm{i}}$ value of $10.8 \mu \mathrm{M}$.

play some part at the transcriptional level. Genistein certainly suppressed promoter I.3 and II transactivity in SK-BR-3 cells, as depicted in Fig. 7 (A). Genistein treatment at $25 \mu \mathrm{M}$ and above significantly suppressed the luciferase activity. The suppression was further supported by the respective enzyme activity (see Fig. 7 (B)).

\section{Discussion}

In the present study, we illustrated that biochanin A was the only aromatase inhibitor among the isoflavones tested. Enzyme kinetic analysis revealed that both competitive and non-competitive inhibitions were involved. Biochanin A could also suppress testosterone-induced MCF-7aro cell proliferation, which was attributed to the reduced aromatase activity. At the transcriptional level, the phytocompound also reduced the aromatase mRNA abundance in the breast cancer cell line SK-BR-3. The promoter utilisation of the human aromatase gene is tissue-specific and promoters I.3 and II have been identified to be responsible for the expression in breast cancer cells including SK-BR- $3^{26}$. We further demonstrated that the transactivation activity of the gene fragment containing promoters I.3 and II was deactivated by biochanin A, and this suppression could be extended to MCF-7 cells. Genistein, which is a major metabolite of biochanin 


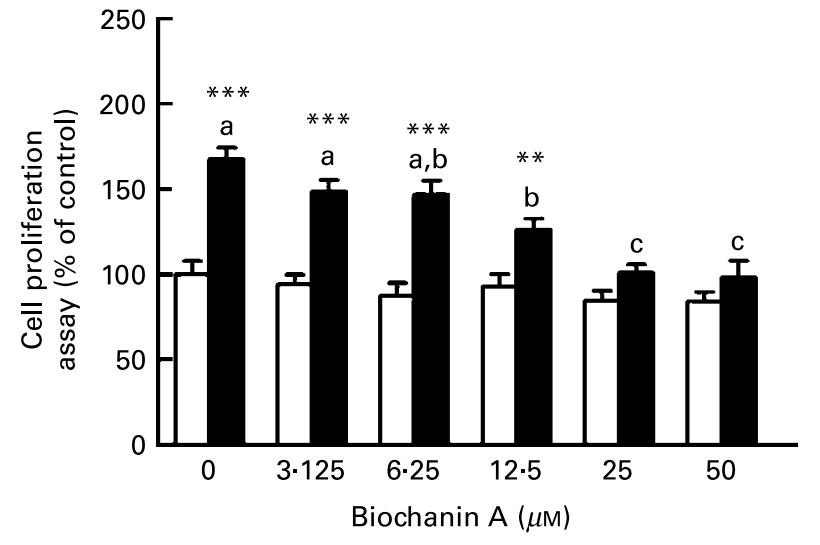

Fig. 3. Effect of biochanin A in reducing testosterone-induced MCF-7aro cell proliferation. MCF-7aro cells were seeded in ninety-six-well plates and maintained in Eagle's minimal essential medium supplemented with $10 \%$ charcoal dextran-treated serum. Cell number was quantified after $48 \mathrm{~h}$ under the influence of testosterone administration $(10 \mathrm{~nm} ; \mathbf{\square})$ or no testosterone $(0 \mathrm{nM} ; \square)$. Values are means ( $n$ ), with their standard errors represeneted by vertical bars. Mean value is significantly higher than that of the cultures without testosterone treatment: ${ }^{\star \star} P<0.01,{ }^{\star \star \star} P<0.001$. ${ }^{\mathrm{a}, \mathrm{b}, \mathrm{c}}$ Mean values with unlike letters are significantly different $(P<0.05)$ within the testostesone treatment group.
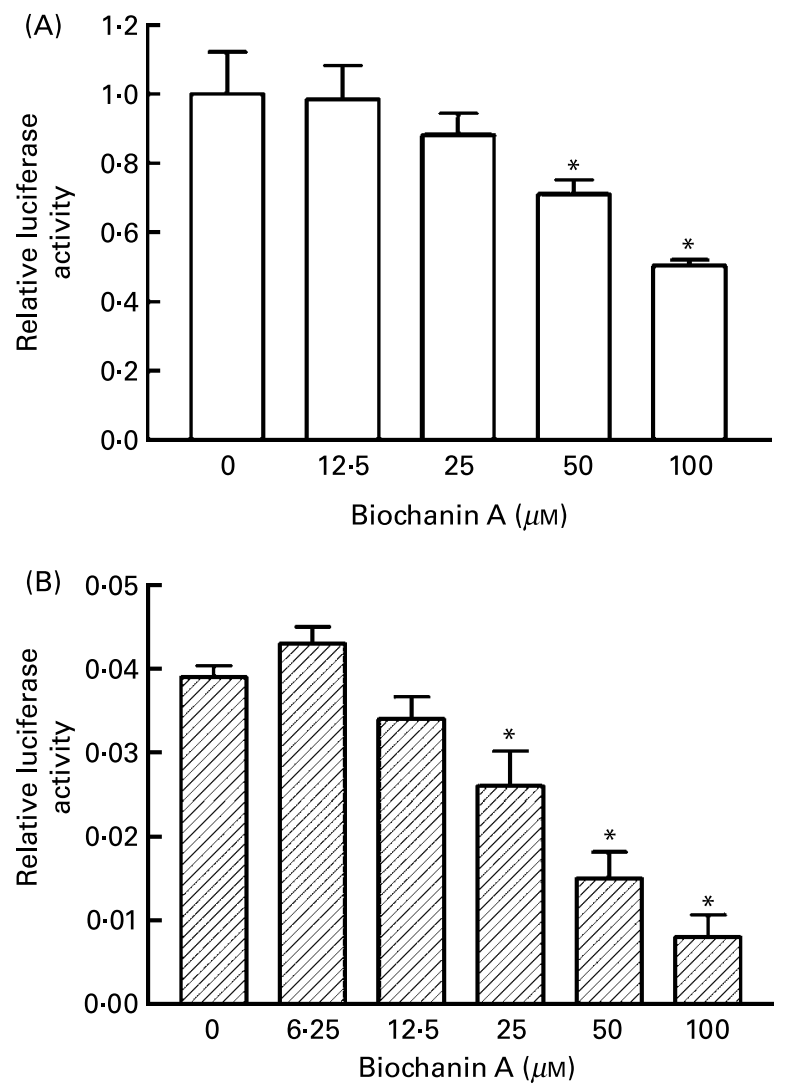

Fig. 4. Biochanin A suppression of cyp19 promoter I.3 and II-driven luciferase activity in SK-BR-3 (A) and MCF-7 cells (B). Cells were seeded in twenty-four-well plates. After $24 \mathrm{~h}$, the cells were transiently transfected with $0.25 \mu \mathrm{g}$ of the CYP19 reporter plasmid and $2.0 \mathrm{ng}$ renilla luciferase control plasmid and the activities of the luciferases were determined in the cell lysate. Values are means ( $n 3)$, with their standard errors represeneted by vertical bars. *Mean value is significantly different from that of the control $(P<0.05)$.

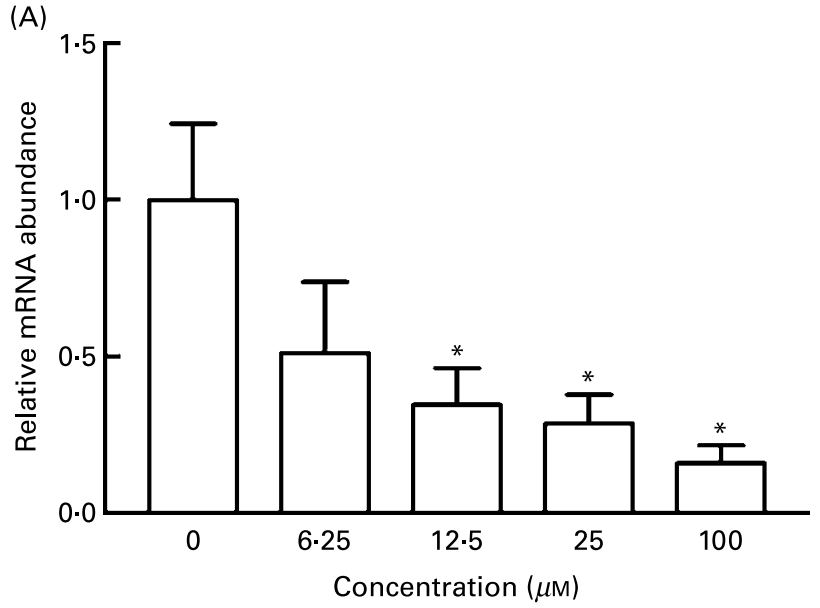

(B)

$$
\frac{\text { Biochanin A }(\mu \mathrm{m})}{10050 \quad 25 \quad 12.5 \quad 6.250}
$$

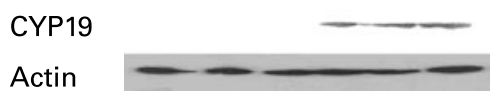

Fig. 5. Messanger RNA (A) and protein expression of aromatase (B) in SKBR-3 cells treated with biochanin A. SK-BR-3 cells were seeded in six-well plates and maintained in McCoy's $5 \mathrm{~A}$ medium supplemented with $10 \%$ charcoal dextran-treated serum. Biochanin A was administered to the cultures for $24 \mathrm{~h}$. (A) CYP19 expression result determined by real-time RT-PCR. Values are means (n 3 ), with their standard errors represeneted by vertical bars. * Mean value is significantly different from that of the control cultures with no biochanin A treatment $(P<0.05)$.(B) Western analysis of aromatase. The image represents one of two blots with similar results. CYP, cytochrome P450.

$\mathrm{A}^{32,33}$, also blocked the transcriptional activity of promoters I. 3 and II in SK-BR-3 cells. This implied that the metabolism of biochanin A could still be effective in suppressing CYP19 expression.

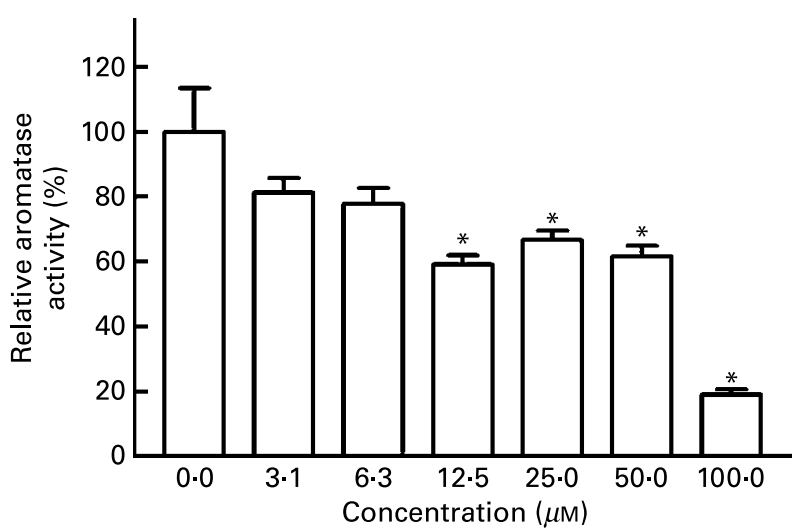

Fig. 6. Inhibitory effect of biochanin A on cytochrome P450 19 enzyme activity in SK-BR-3 cells. SK-BR-3 cells were seeded in six-well plates and maintained in McCoy's $5 \mathrm{~A}$ medium supplemented with $10 \%$ charcoal dextran-treated serum. Biochanin A was administered to the cultures for $24 \mathrm{~h}$. The cultures were switched to serum-free medium upon assay. $\left[1 \beta-{ }^{3} \mathrm{H}\right] \mathrm{an}-$ drostenedione was administered and incubated for $1 \mathrm{~h}$. Significant inhibition was seen at $25 \mu \mathrm{M}$ and above. The $50 \%$ inhibitory concentration value was determined to be $40 \mu \mathrm{M}$. Values are means $(n 3)$, with their standard errors represeneted by vertical bars. *Mean value is significantly different from that of the control $(P<0.05)$. 

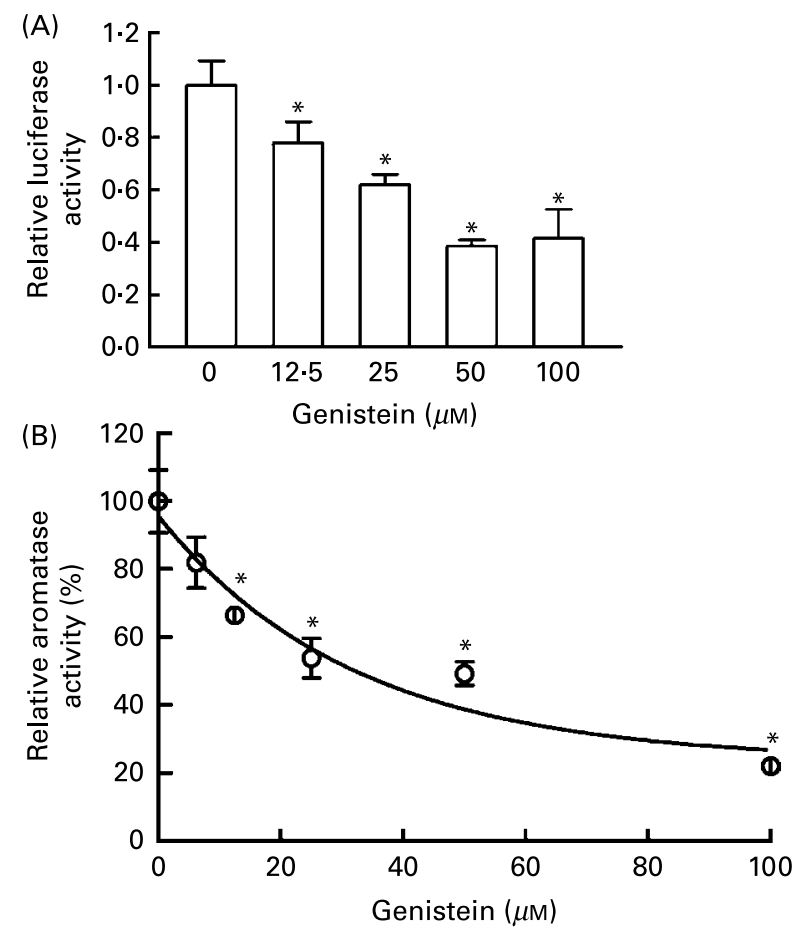

Fig. 7. Suppressive effect of genistein on cytochrome P450 19 in SK-BR-3 cells. SK-BR-3 cells were seeded in six-well plates and maintained in McCoy's 5A medium supplemented with $10 \%$ charcoal dextran-treated serum. Genistein was administered to the cultures for $24 \mathrm{~h}$. (A) mRNA expression; (B) aromatase activity. Significant inhibition was seen in both mRNA expression and aromatase activity at $12.5 \mu \mathrm{M}$ and above. Values are means $(n 3)$, with their standard errors represeneted by vertical bars. *Mean value is significantly different from that of the control $(P<0.05)$

Biochanin A at $100 \mathrm{nM}$ and $10 \mu \mathrm{M}$ was found to be ineffective in inhibiting CYP19 at the enzyme and expression levels in human granulose-luteal cells ${ }^{34}$. The differences in treatment concentration and cell type could separate this and the present study. Genistein, on the other hand, displays a similar suppressive effect on CYP19 in the former study. Other phytochemicals have also been reported to be aromatase inhibitors. Extract of red wine inhibits aromatase activity ${ }^{35}$, and reduces mammary hyperplasia in transgenic mice over-expressing CYP19. The active ingredients in the extract could be procyanidin $\mathrm{B}$ dimers $^{36}$ and resveratrol ${ }^{29}$. Chalcones, which are a subclass of flavonoid, display inhibitory actions on aromatase in placental microsomes with $\mathrm{IC}_{50}$ values greater than or equal to $34.6 \mu \mathrm{m}^{37}$. Kao et al. ${ }^{38}$ have shown that the flavonone naringinin is a stronger inhibitor than the chalcones. In the present study biochanin A was the only isoflavone demonstrated to inhibit the enzyme activity. Given the structural resemblance between biochanin A and genistein, the methyl ether group substitute at the $4^{\prime} \mathrm{C}$ position may generate a significant steric hindrance in the active site of the enzyme.

At the transcriptional level, many factors have been described for the regulation of aromatase. Simpson et al. ${ }^{39}$ have reviewed that cyclic AMP, phorbol esters, dexamethasone, PG E2, transforming growth factor- $\beta$, and $\gamma$-interferon increase the transcriptional activity, whereas cyclo-oxygenase inhibitors suppress the mRNA expression ${ }^{40}$. Kinoshita \& Chen ${ }^{41}$ have previously reported that mitogen-activated protein kinase inhibitor may reduce CYP19 transcription in breast cells, and biochanin A may inhibit mitogen-activated protein kinase in a different cell system ${ }^{42}$. This could also be a potential deactivating pathway in CYP19 transcription.

Many studies have documented biochanin A's chemopreventive effect on breast cancer. The isoflavone can protect against nitrosomethylurea-induced mammary carcinogenesis in rats $^{43}$, and mammary tumour virus-induced spontaneous breast cancer in mice ${ }^{44}$. In the context of drug or xenobiotic metabolism, biochanin A also inhibits CYP1 ${ }^{45}$ and induces UDP-glucuronosyltransferase ${ }^{46}$ enzyme activities. The results of the present study provided a possible chemoprotective pathway for the isoflavone.

The biological relevance of biochanin $\mathrm{A}$ as a nutraceutical for preventing breast cancer has yet to be established. Like genistein, it exhibits biphasic effects on mammary cell proliferation. The phytochemical is growth inhibitory to human mammary epithelial cells and MCF-7 cells with $\mathrm{IC}_{50}$ values of about $20 \mu \mathrm{M}$ after a $4 \mathrm{~d}$ incubation period ${ }^{32}$, whereas it is growth stimulatory at a half maximal effective concentration $\left(\mathrm{EC}_{50}\right)$ value of $9 \mathrm{nM}$ after incubation for $6 \mathrm{~d}^{24}$. In the present study, biochanin A had no significant effect on MCF-7aro cell proliferation in the testosterone-less treatment group after a $24 \mathrm{~h}$ incubation period.

In human subjects ${ }^{33}$ and the MCF-7 cell model ${ }^{32}$, the phytocompound can be metabolised into genistein, biochanin $\mathrm{A}$ conjugates or hydroxy metabolites. Assuming the metabolites have an effect comparable with biochanin A, an oral dosage of $50 \mathrm{mg} / \mathrm{kg}$ could be able to sustain an aromatase-suppressing plasma concentration with respect to a pharmacokinetic study performed in rats ${ }^{47}$.

In summary, the present study suggested that biochanin A inhibited the enzyme activity and suppressed the transcriptional control of CYP19 in breast cancer cells.

\section{References}

1. International Agency for Research on Cancer (1999) Hormonal Contraception and Post-menopausal Hormonal Therapy. IARC Monographs on the Evaluation of Carcinogenic Risks to Humans, vol. 72, Lyon, France: IARC Press.

2. Pike MC \& Spicer DV (1993) The chemoprevention of breast cancer by reducing sex steroid exposure: perspectives from epidemiology. J Cell Biochem Suppl 17G, 26-36.

3. Toniolo PG, Levitz M, Zeleniuch-Jacquotte A, Banerjee S, Koenig KL, Shore RE, Strax P \& Pasternack BS (1995) A prospective study of endogenous estrogens and breast cancer in postmenopausal women. J Natl Cancer Inst 87, 190-197.

4. Adlercreutz H, Gorbach SL, Goldin BR, Woods MN, Dwyer JT \& Hamalainen E (1994) Estrogen metabolism and excretion in oriental and Caucasian women. J Natl Cancer Inst 86, 1076-1082.

5. Colditz GA (1999) Hormones and breast cancer: evidence and implications for consideration of risks and benefits of hormone replacement therapy. J Womens Health 8, 347-357.

6. Liehr JG (2000) Is estradiol a genotoxic mutagenic carcinogen? Endocr Rev 21, 40-54.

7. Liehr JG, Fang WF, Sirbasku DA \& Ari-Ulubelen A (1986) Carcinogenicity of catechol estrogens in Syrian hamsters. J Steroid Biochem 24, 353-356. 
8. Li JJ \& Li SA (1987) Estrogen carcinogenesis in Syrian hamster tissues: role of metabolism. Fed Proc 46, 1858-1863.

9. Zhu BT \& Conney AH (1998) Functional role of estrogen metabolism in target cells: review and perspectives. Carcinogenesis 19, 1-27.

10. Yared E, McMillan TJ \& Martin FL (2002) Genotoxic effects of oestrogens in breast cells detected by the micronucleus assay and the Comet assay. Mutagenesis 17, 345-352.

11. Zhang F, Swanson SM, van Breemen RB, Liu X, Yang Y, Gu C \& Bolton JL (2001) Equine estrogen metabolite 4-hydroxyequilenin induces DNA damage in the rat mammary tissues: formation of single-strand breaks, apurinic sites, stable adducts, and oxidized bases. Chem Res Toxicol 14, 1654-1659.

12. Yoshidome K, Shibata MA, Couldrey C, Korach KS \& Green JE (2000) Estrogen promotes mammary tumour development in $\mathrm{C} 3(1) / \mathrm{SV} 40$ large $\mathrm{T}$-antigen transgenic mice: paradoxical loss of estrogen receptor (expression during tumour progression. Cancer Res 60, 6901-6910.

13. Tsai MJ \& O'Malley BW (1994) Molecular mechanisms of action of steroid/thyroid receptor superfamily members. Ann Rev Biochem 63, 451-486.

14. Dickson RB, Kasid A, Huff KK, Bates SE, Knabbe C, Bronzert D, Gelmann EP \& Lippman ME (1987) Activation of growth factor secretion in tumorigenic states of breast cancer induced by $17 \beta$-estradiol or v-Ha-ras oncogene. Proc Natl Acad Sci USA 84, 837-841.

15. Leung LK \& Wang TT (1999) Paradoxical regulation of Bcl-2 family proteins by $17 \beta$-oestradiol in human breast cancer cells MCF-7. Br J Cancer 81, 387-392.

16. Watson CS, Norfleet AM, Pappas TC \& Gametchu B (1999) Rapid actions of estrogens in GH3/B6 pituitary tumour cells via a plasma membrane version of estrogen receptor- $\alpha$. Steroids 64, 5-13.

17. Means GD, Mahendroo MS, Corbin CJ, Mathis JM, Powell FE, Mendelson CR \& Simpson ER (1989) Structural analysis of the gene encoding human aromatase cytochrome P-450, the enzyme responsible for estrogen biosynthesis. J Biol Chem 264, 19385-19391.

18. Toda K, Terashima M, Kawamoto T, et al. (1990) Structural and functional characterization of human aromatase P-450 gene. Eur J Biochem 193, 559-565.

19. Harada N, Yoshimura N \& Honda S (2003) Unique regulation of expression of human aromatase in the placenta. J Steroid Biochem Mol Biol 86, 327-334.

20. Lee KM, Abel J, Ko Y, et al. (2003) Genetic polymorphisms of cytochrome P450 19 and 1B1, alcohol use, and breast cancer risk in Korean women. Br J Cancer 88, 675-678.

21. Cuzick J (2003) Aromatase inhibitors in prevention - data from the ATAC (arimidex, tamoxifen alone or in combination) trial and the design of IBIS-II (the second International Breast Cancer Intervention Study). Recent Results Cancer Res 163, 96-103, 264-266.

22. Jeong H-J, Shin YG, Kim L-H \& Pezzuto JM (1999) Inhibition of aromatase activity by flavonoids. Arch Pharm Res 22, 309-312.

23. Kao YC, Zhou C, Sherman M, Laughton CA \& Chen S (1998) Molecular basis of the inhibition of human aromatase (estrogen synthethase) by flavone and isoflavone phytoestrogens: a sitedirected mutagenesis study. Environ Health Perspect 106, $85-92$.

24. Van Meeuwen JA, Korthagen N, de Jong PC, Piersma AH \& van den Berg M (2007) (Anti)estrogenic effects of phytochemicals on human primary mammary fibroblasts, MCF-7 cells and their co-culture. Toxicol Appl Pharmacol 221, 372-383.

25. Brueggemeier RW, Hackett JC \& Diaz-Cruz ES (2005) Aromatase inhibitors in the treatment of breast cancer. Endocr Reviews 26, 331-345.
26. Chen S, Zhou D, Okubo T, Kao Y-C \& Yang C (1999) Breast tumor aromatase: functional role and transcriptional regulation. Endocr Relat Cancer 6, 149-156.

27. Zhou DJ, Pompon D \& Chen SA (1990) Stable expression of human aromatase complementary DNA in mammalian cells: a useful system for aromatase inhibitor screening. Cancer Res 50, 6949-6954.

28. Grube BJ, Eng ET, Kao YC, Kwon A \& Chen S (2001) White button mushroom phytochemicals inhibit aromatase activity and breast cancer cell proliferation. J Nutr 131, 3288-3293.

29. Wang Y, Lee KW, Chan FL, Chen S \& Leung LK (2006) The red wine polyphenol resveratrol displays bi-level inhibition on aromatase in breast cancer cells. Toxicol Sci 92, 71-77.

30. Mosmann T (1983) Rapid colorimetric assay for cellular growth and survival: application to proliferation and cytotoxicity assays. J Immunol Methods 65, 55-63.

31. Wang Y, Chan FL, Chen S \& Leung LK (2005) The plant polyphenol butein inhibits testosterone-induced proliferation in breast cancer cells expressing aromatase. Life Sci 77, 39-51.

32. Peterson TG, Coward L, Kirk M, Falany CN \& Barnes S (1996) The role of metabolism in mammary epithelial cell growth inhibition by the isoflavones genistein and biochanin A. Carcinogenesis 17, 1861-1869.

33. Heinonen S-M, Wahala K \& Adlercreutz H (2004) Identification of urinary metabolites of the red clover isoflavones formononetin and biochanin A in human subjects. J Agric Food Chem 52, 6802-6809.

34. Rice S, Mason HD \& Whitehead SA (2006) Phytoestrogens and their low dose combinations inhibit mRNA expression and activity of aromatase in human granulose-luteal cells. J Steroid Biochem Mol Biol 101, 216-225.

35. Eng ET, Williams D, Mandava U, Kirma N, Tekmal RR \& Chen S (2001) Suppression of aromatase (estrogen synthetase) by red wine phytochemicals. Breast Cancer Res Treat 67, 133-146.

36. Eng ET, Ye J, Williams D, Phung S, Moore RE, Young MK, Gruntmanis U, Braustein G \& Chen S (2003) Suppression of estrogen biosynthesis by procyanidin dimers in red wine and grape seeds. Cancer Res 63, 8516-8522.

37. Le Bail JC, Pouget C, Fagnere C, Basly JP, Chulia AJ \& Habrioux G (2001) Chalcones are potent inhibitors of aromatase and 17(-hydroxysteroid dehydrogenase activities. Life Sci $\mathbf{6 8}$, $751-761$.

38. Kao YC, Zhou C, Sherman M, Laughton CA \& Chen S (1998) Molecular basis of the inhibition of human aromatase (estrogen synthetase) by flavone and isoflavone phytoestrogens: a sitedirected mutagenesis study. Environ Health Perspect 106, $85-92$.

39. Simpson ER, Zhao Y, Agarwal VR, et al. (1997) Aromatase expression in health and disease. Recent Prog Horm Res 52, $185-213-213-214$.

40. Diaz-Cruz ES, Shapiro CL \& Brueggemeier RW (2005) Cyclooxygenase inhibitors suppress aromatase expression and activity in breast cancer cells. J Clin Endocrinol Metab 90, $2563-2570$

41. Kinoshita Y \& Chen S (2003) Induction of aromatase (CYP19) expression in breast cancer cells through a nongenomic action of estrogen receptor $\alpha$. Cancer Res 63, 3546-3555.

42. Vanden Berghe W, Dijsselbloem N, Vermeulen L, Ndlovu N, Boone E \& Haegeman G (2006) Attenuation of mitogen- and stress-activated protein kinase-1-driven nuclear factor- $\mathrm{\kappa B}$ gene expression by soy isoflavones does not require estrogenic activity. Cancer Res 66, 4852-4862.

43. Gotoh T, Yamada K, Yin H, Ito A, Kataoka T \& Dohi K (1998) Chemoprevention of $N$-nitroso- $N$-methylurea-induced rat mammary carcinogenesis by soy foods or biochanin A. Jpn $J$ Cancer Res 89, 137-142. 
44. Mizunuma H, Kanazawa K, Ogura S, Otsuka S \& Nagai H (2002) Anticarcinogenic effects of isoflavones may be mediated by genistein in mouse mammary tumor virus-induced breast cancer. Oncology 62, 78-84.

45. Chan HY, Wang H \& Leung LK (2003) The red clover (Trifolium pratense) isoflavone biochanin A modulates the biotransformation pathways of 7,12-dimethylbenz-[a]anthracene. $\mathrm{Br} \mathrm{J}$ Nutr 90, 87-92.
46. Sun XY, Plouzek CA, Henry JP, Wang TT \& Phang JM (1998) Increased UDP-glucuronosyltransferase activity and decreased prostate specific antigen production by biochanin A in prostate cancer cells. Cancer Res 58, 2379-2384.

47. Moon YJ, Sagawa K, Frederick K, Zhang S \& Morris ME (2006) Pharmacokinetics and bioavailability of the isoflavone biochanin $\mathrm{A}$ in rats. AAPS $J$ 8, E433-E442. 